\title{
Lea Bouwmeester
}

Functie/organisatie: directeur Nederlandse Diabetes Federatie (tot 1 okt), en

senior adviseur e-health bij ECP | Platform voor de InformatieSamenleving sport: hardlopen

Opvallendste prestatie: "Samen mijn dochter van vier de Haagse City-Pier-City. Anderhalve kilometer in de stromende regen.“

\section{Waarom hardlopen?} “Ik heb altijd heel veel in teamverband gedaan en zocht iets dat helemaal van mezelf was en dat ik op elk moment kon doen. Met judo, atletiek, handbal, bergbeklimmen, body boarden moet je spullen en plekken en tijden organiseren. Met hardlopen trek je je schoenen aan en je gaat. Sinds mijn vijftiende is dat mijn favoriete sport én uitlaatklep."

2. Wat is de aantrekkingskracht?

'Die totale vrijheid, ook in mijn hoofd. Allerlei zaken waar je mee bezig bent worden door elkaar geschud en vervolgens geordend. Dingen worden echt opgelost. Dat ik ineens zie: ja, zó moet het. Dat ervaar ik als iets magisch. En het is gewoon lekker om te voelen dat je echt wat hebt gedaan met je lijf."
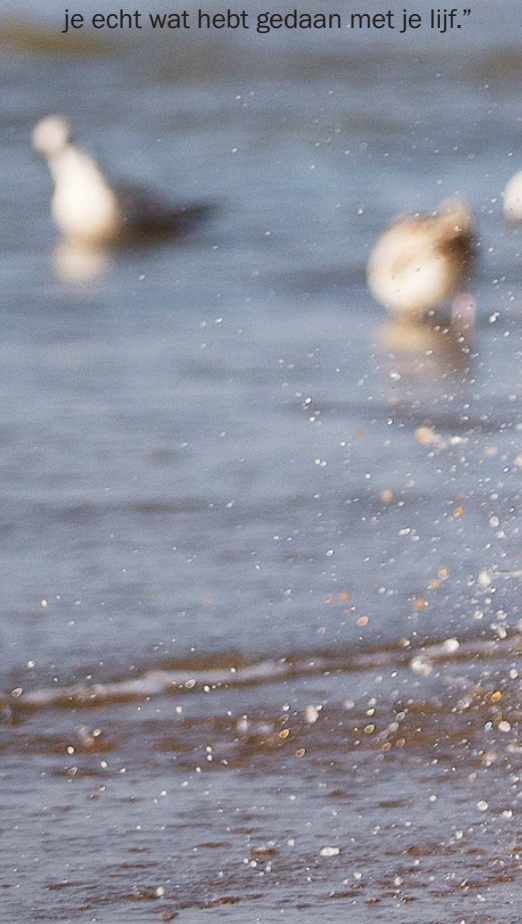